\title{
Belowground microbial symbiont enhances plant susceptibility to a spider mite through change in soybean leaf quality
}

\author{
Noboru Katayama $\cdot$ Takaaki Nishida $\cdot$ \\ Zhi Qi Zhang • Takayuki Ohgushi
}

Received: 19 September 2009/Accepted: 18 February 2010/Published online: 14 April 2010

(C) The Society of Population Ecology and Springer 2010

\begin{abstract}
To examine how rhizobia affect the chemical and nutrient status in leaves of soybean (Glycine max L.), and how rhizobia change plant susceptibility to a generalist spider mite (Tetranycus urticae), we cultivated root-nodulating soybeans $(\mathrm{R}+)$ and their non-nodulating mutant $(\mathrm{R}-)$ in a common garden. We experimentally fertilized the plants with nitrogen to examine effects of rhizobia on the plant traits and plant susceptibility to spider mites at different nitrogen levels. $\mathrm{R}+$ plants produced more leaves containing greater nitrogen and less total phenolics than $\mathrm{R}-$ plants. Spider mites fed on $\mathrm{R}+$ leaves produced more eggs than those fed on $\mathrm{R}-$ leaves. The positive effect of rhizobia on spider mite fecundity could be due to an increase in foliar $\mathrm{N}$ content and/or to a decrease in concentration of phenolics. Although root nodule mass did not differ among different nitrogen levels, ureide-N, an indicator of nitrogen provided by rhizobia, in xylem sap decreased at moderate and high soil nitrogen levels. Therefore, we expected that rhizobia effects on egg production of the spider mite would decrease in high soil nitrogen conditions. However, the effect of rhizobia was still maintained even at high soil nitrogen levels. Thus, soil nitrogen and rhizobia may independently affect the reproductive performance of the spider mite.
\end{abstract}

Keywords Above- and belowground interactions . Glycine max · Nitrogen · Phenolics · Rhizobia · Ureide

N. Katayama $(\bowtie) \cdot$ T. Nishida · Z. Q. Zhang · T. Ohgushi Center for Ecological Research, Kyoto University, 509-3 Hirano 2-chome, Ohtsu, Shiga 520-2113, Japan e-mail: n-kata@ecology.kyoto-u.ac.jp

\section{Introduction}

Ecological communities are structurally organized into complex networks by direct and indirect interactions (Ohgushi 2005; Bascompte and Jordano 2007; Ohgushi et al. 2007; Ings et al. 2009). In terrestrial systems, plantmediated indirect interactions are ubiquitous, and recent studies have revealed the importance of plant-mediated indirect interactions in population dynamics and/or community organization of arthropods (Van Zandt and Agrawal 2004; Ohgushi 2005, 2008; Poelman et al. 2008). Although we have made great advances in understanding direct and indirect plant-arthropod interactions, how microbial symbionts living in plant tissues affect aboveground plantarthropod interactions still remains unclear. Because plants harbor various microbes that strongly influence the chemical and nutrient status of host plants (Clay 1988; Gange and West 1994; Chaneton and Omacini 2007), the microbial effects can expand to aboveground arthropod populations and communities through changes in plant traits (Omacini et al. 2001; Rudgers and Clay 2008; Hartley and Gange 2009).

Terrestrial plants have symbiotic mutualisms with belowground microbes such as mycorrhizal fungi and/or nitrogen-fixing bacteria (Smith and Read 1997; Patriarca et al. 2002). Mycorrhizal fungi provide nutrients (mainly nitrogen and phosphorus) to host plants (Edathil et al. 1996; Smith and Read 1997), and improve the chemical and nutrient status of leaves (Gange and West 1994; Goverde et al. 2000). These changes in host plant quality affect arthropod herbivores (Hartley and Gange 2009; Koricheva et al. 2009). For example, arbuscular mycorrhizal fungi increase carbon-based chemical defense substances (acucubin and catalpol) in leaves of plantain (Plantago lanceolata) and, as a result, reduce leaf-chewing 
herbivory (Gange and West 1994). Vicari et al. (2002) reported that larval survival of a noctuid moth (Phlogophora meticulosa) fed on perennial ryegrass (Lolium perenne) decreased when the plants were infected by mycorrhizal fungi. In contrast, the survival and body weight of larvae of the common blue butterfly (Polyommatus icarus) fed on mycorrhizal bird's-foot trefoil (Lotus corniculatus) were greater than those of the same species fed on non-mycorrhizal plants (Goverde et al. 2000). Thus, there is a growing body of evidence that mycorrhizal fungi can positively or negatively affect the performance of aboveground arthropods (Gange 2007; Hartley and Gange 2009; Koricheva et al. 2009).

Nitrogen-fixing bacteria are another important group that has obligate symbiosis with plants. In particular, rhizobia live in root nodules of legume plants and provide synthesized nitrogen compounds $\left(\mathrm{NH}_{4}{ }^{+}\right)$from $\mathrm{N}_{2}$ in the atmosphere to the host plant (Patriarca et al. 2002). In the root nodulation, there is a reciprocal signaling system between rhizobia and legume hosts (Miklashevichs et al. 2001). This nodulating process is regulated by multiple nod genes of the legumes and rhizobia (van Rhijn and Vanderleyden 1995). Therefore, legume mutants lacking nod genes cannot induce root nodules.

Although Kempel et al. (2009) first documented the positive effects of rhizobia on the body weight of lepidopteran caterpillars and the population growth of aphids in a greenhouse experiment, using root-nodulating and non-nodulating clovers (Trifolium repens L.), we know little about the effects of nitrogen-fixing bacteria on the performance of aboveground arthropod herbivores.

To learn more about such effects, we examined how rhizobia modify the chemical and nutrient status of leaves of soybean (Glycine max L.) and how rhizobia affect plant susceptibility to a generalist spider mite (Tetranycus urticae). We assessed the plant susceptibility to spider mites by measuring the egg production of mites fed on leaves of rhizobia associated plants. Previous studies have determined plant susceptibility to the spider mite evaluated by assessing the fecundity of female mites (Stonor and Stringfellow 1967; Choh et al. 2004; Saeidi and Mallik 2006). In this study, we experimentally fertilized soybeans with nitrogen to examine the effects of rhizobia on eggs laid by the mite at two or three nitrogen levels. This is because rhizobia-legume associations are influenced by soil nitrogen (Evans 1982; Hardarson and Zapata 1984). Since soil nitrogen usually inhibits root nodulation and/or rhizobia activity (Evans 1982; Hardarson and Zapata 1984), the effect of rhizobia on plant susceptibility to herbivores may depend on soil nitrogen conditions.

In this study we addressed the following questions: (1) Do rhizobia change plant biomass, carbon, nitrogen, or secondary metabolic substances (total phenolics) in leaves?
(2) Do rhizobia influence egg production by spider mites? (3) How does rhizobia activity change, depending on the soil nitrogen level? (4) How does soil nitrogen influence the effect of rhizobia on the egg-laying of spider mites?

\section{Materials}

Soybean (G. max) is an annual legume and is a native plant in East Asia. In central Japan, soybean seeds are sown from late June to early July, and the plants begin to bear flowers in August. Soybean produces pods in September, and the pods gradually mature during autumn. Several bacteria, Bradyrhizobium japonicum, B. elkani, and Rhizobium fre$d i i$, form root nodules on soybean roots. We inoculated B. japonicum on soybean seeds (see detailed method in "Experimental design"). Bradyrhizobium japonicum (Konryukin Mame-Zo ${ }^{\circledR}$ ) was provided by the Federation of Tokachi Agricultural Cooperative Association. In this study, we used two soybean strains to compare the rhizobia effect. One is a root-nodulating strain (cv. Fujimishiro: $\mathrm{R}+$ ) and the other is a non-nodulating strain (cv. Touzan no. 90: $\mathrm{R}-$ ). Touzan no. 90 was made by backcross to Fujimishiro after crossing between Fujimishiro and T201 which was another non-nodulating soybean (K. Takahashi, personal communication). T201 has a mutation in the $r j_{1}$ locus that is responsible for root hair-curling when taking rhizobium into the root (Williams and Lynch 1954; Mathews et al. 1987; Suganuma et al. 1991). Therefore, Touzan no. 90 is closely related to Fujimishiro except for root nodulation. Seeds of the soybean strains were provided by the Laboratory of Plant Breeding, Faculty of Agriculture, Kyoto University.

To determine plant susceptibility to the spider mite, we measured the number of eggs laid by spider mites (T. urticae). The spider mite is a generalist herbivore that is distributed throughout the world and feeds on more than 900 plant species (Navajas 1998). The spider mites had been reared on lima bean plants (Phaseolus lunatus L.) in a climate-controlled greenhouse $\left(25 \pm 2^{\circ} \mathrm{C}, 50-70 \% \mathrm{RH}\right.$, and natural light condition) for more than 3 years.

\section{Experimental design}

We carried out a common garden experiment to examine the effects of rhizobia (R) on plant biomass, chemical and nutrient status of leaves, and rhizobia activity at three soil nitrogen levels $(\mathrm{F}-, \mathrm{F}+$, and $\mathrm{F}++)$, and a laboratory experiment to examine plant susceptibility to spider mites at two soil nitrogen levels ( $\mathrm{F}-$ and $\mathrm{F}++$ ). On June 15 in 2007, 150 and 250 surfaces of R+ and R- soybean seeds, respectively, were sterilized for $3 \mathrm{~min}$ in saturated $1 \%$ sodium hypochlorite solution and were germinated on wet 
cotton. We sprinkled lumps of soil containing B. japonicum on the surfaces of 5-day-old germinated seeds and transplanted them individually into polyethylene pots $(5 \mathrm{~cm}$ in diameter and $5 \mathrm{~cm}$ in depth) filled with a 1:1 mixture of brunizen and sand, which had been autoclaved-sterilized at $127^{\circ} \mathrm{C}$ for $72 \mathrm{~min}$. The black soil and sand are low in nutrients [available nitrogen (ammonium-N + nitrate- $\mathrm{N}$ ) concentration: $55 \pm 25 \mu \mathrm{g} /$ soil-g (mean $\pm \mathrm{SE}, \quad n=10$ ), N. Katayama, unpublished data]. Two weeks later, we separately transplanted the seedlings into large polyethylene pots $(20 \mathrm{~cm}$ in diameter and $20 \mathrm{~cm}$ in depth) filled with the autoclaved-sterilized soil. Phosphorus and potassium were applied into all pots prior to transplanting (calcium superphosphate $1.5 \mathrm{~g}$ per pot, $\mathrm{K}_{2} \mathrm{SO}_{4} 1.5 \mathrm{~g}$ per pot). We added $0.3 \mathrm{~g}$ of ammonium nitrate to one-third of the pots ( $\mathrm{F}+$ treatment) and $0.6 \mathrm{~g}$ of ammonium nitrate to other one-third of the pots $(\mathrm{F}++$ treatment $)$. We did not add nitrogen fertilizer to the remaining pots ( $\mathrm{F}-$ treatment).

On 29 June we randomly placed 101 pots of $\mathrm{R}+$ plants and 171 pots of $\mathrm{R}-$ plants, which contained three different soil nitrogen levels $(\mathrm{F}-, \mathrm{F}+$ and $\mathrm{F}++)$, in eight lines in a common garden of the Center for Ecological Research of Kyoto University $\left(34^{\circ} 58^{\prime} 17^{\prime \prime} \mathrm{N}, 135^{\circ} 57^{\prime} 32^{\prime \prime} \mathrm{E}\right.$, Otsu city, Japan). The lines were spaced at $80-\mathrm{cm}$ intervals, and the pots within each line were spaced at $80-\mathrm{cm}$ intervals. We additionally applied ammonium nitrate to each pot with $\mathrm{F}+$ $(0.3 \mathrm{~g})$ and $\mathrm{F}++(0.6 \mathrm{~g})$ treatments on $18 \mathrm{July}, 6$ August, 25 August, and 14 September.

\section{Analysis of xylem sap}

On 4 September, we randomly selected 25, 24, 25, 14, 15, and 14 of the $\mathrm{R}-\mathrm{F}-, \mathrm{R}-\mathrm{F}+, \mathrm{R}-\mathrm{F}++, \mathrm{R}+\mathrm{F}-, \mathrm{R}+\mathrm{F}+$, and $\mathrm{R}+\mathrm{F}++$ plants, respectively. To collect xylem sap for assessing rhizobia activity, we cut the aboveground parts, leaving $5 \mathrm{~cm}$ of a stem, at 4 a.m., and covered the top of the stem with $1 \mathrm{~g}$ of cotton wool. The cotton wool was wrapped with cellophane film to prevent evaporation from the exuded xylem sap. After $5 \mathrm{~h}$, we collected the cotton wool of the individual plants. Xylem sap was collected into a 100-ml centrifuge tube by spinning out the cotton, using a centrifuge $(3,500 \mathrm{rpm}$, for $1 \mathrm{~h})$. The collected xylem sap was filtered through a Millipore filter $(0.20 \mu \mathrm{m})$ and transferred into a 1-ml tube. The samples were then stored in a freezer $\left(-20^{\circ} \mathrm{C}\right)$ until chemical analysis.

In this study, we assessed rhizobia activity using the relative ureide method (Herridge and Peoples 1990). Soybean xylem sap contains nitrogen as ureides (allantoin and allantoic acid), amino acids (mainly asparagine and glutamine), and nitrate (Matsumoto et al. 1977). Using xylem sap collected from field-grown soybeans, Streeter (1979) reported that ureide was the principal form of nitrogen transported from nodulated roots to soybean shoots. In contrast, nitrate and amino acids in xylem sap are major forms of nitrogen derived from soil (Unkovich and Pate 2000). Therefore, we estimated rhizobia activity by determining the relative ureide concentration.

The relative ureide concentration (RU, \%) was calculated using the following equation:

$$
\begin{aligned}
\mathrm{RU}(\%)= & \text { Ureide- } \mathrm{N} /(\text { Ureide- } \mathrm{N}+\text { Nitrate- } \mathrm{N}+\text { Amino- } \mathrm{N}) \\
& \times 100
\end{aligned}
$$

Ureide-N was determined by the Young-Conway method (Young and Conway 1942) using $50 \mu \mathrm{l}$ of xylem sap. Amino-N was determined by the ninhydrin method (Herridge 1984) using $50 \mu$ l of xylem sap. Nitrate-N was measured by Cataldo's method (Cataldo et al. 1974) using $50 \mu$ of xylem sap.

Plant biomass and leaf quality

We brought the aboveground plant parts to a laboratory, and divided them into leaves and other parts (i.e., stems and reproductive organs including buds, flowers, and pods). After collection of the xylem sap, we dug up plant roots, separated the root nodules from the roots, and counted the number of root nodules.

Then, stems, reproductive organs, root nodules, and roots were oven-dried at $60^{\circ} \mathrm{C}$ for $48 \mathrm{~h}$. The leaves were dried in a desiccator with silica gel at room temperature $\left(22-25^{\circ} \mathrm{C}\right)$. After drying, we measured the total plant dry mass, dry mass of the root nodules, and dry mass of the leaves.

The dry leaf samples were powdered using a mill for leaf chemical analysis. The carbon and nitrogen contents of the leaves were measured using an elemental analyzer (CHN Corder MT-3, Yanaco, Kyoto, Japan) with $20 \mathrm{mg}$ powder samples. Total phenolics in a $20-\mathrm{mg}$ leaf powder sample were extracted with $50 \%$ methanol $(10 \mathrm{ml})$ for $1 \mathrm{~h}$ in a $40^{\circ} \mathrm{C}$ ultrasonic bath, and the concentration $(\mathrm{mg} / \mathrm{g})$ was measured using the Folin-Ciocalteu method (JulkunenTiitto 1985).

\section{Bioassay using spider mites}

On 26 September in 2007 we collected a top leaf each from $6,12,6$, and 9 of $\mathrm{R}-\mathrm{F}-, \mathrm{R}-\mathrm{F}++, \mathrm{R}+\mathrm{F}-$, and $\mathrm{R}+\mathrm{F}++$ plants cultivated in a common garden, respectively. Pieces from each sampled leaf were punched out using a cork borer to obtain 5-8 leaf discs $8 \mathrm{~mm}$ in diameter. One adult female mite was placed on each leaf disc on water-saturated cotton in a petri dish. The leaf discs inoculated with the mites were placed in an incubator $\left(25 \pm 2{ }^{\circ} \mathrm{C}, 60-70 \%\right.$ $\mathrm{RH}$ and 16L8D); $72 \mathrm{~h}$ after mite inoculation, we checked whether the spider mites were alive and counted the number of eggs on each leaf disc using a microscope. 
When inoculated mites had died during the experimental period, they were excluded from further analysis.

Statistical procedure

The number and dry mass of root nodules of $\mathrm{R}+$ plants were compared between $\mathrm{F}$ treatments by one-way ANOVA. Ureide- $\mathrm{N}$, amino acid-N, and nitrate- $\mathrm{N}$ in xylem sap were compared between $\mathrm{R}$ and $\mathrm{F}$ treatments by twoway ANOVA. The relative ureide ratio (RU, \%) was arcsin-transformed, and was compared between $\mathrm{F}$ treatments by one-way ANOVA. Total biomass and leaf mass were compared between the $\mathrm{R}$ and $\mathrm{F}$ treatments by two-way ANOVA. Carbon, nitrogen, and total phenolics in leaves, and egg production of spider mite were compared between $\mathrm{R}$ and $\mathrm{F}$ treatments by two-way ANOVA. The survival rate of spider mites in the experimental period on each plant was compared between $\mathrm{F}$ and $\mathrm{R}$ treatments by a two-way nominal logistic regression analysis. The Tukey-Kramer test was used as a post hoc test for any parameters between treatments. In two-way ANOVAs, we conducted post hoc tests, using each treatment independent of $\mathrm{R}$ and $\mathrm{F}$ treatments when significant interactions were detected between $\mathrm{R}$ and $\mathrm{F}$ treatments (Zar 1999).

\section{Results}

\section{Root nodules}

The numbers of root nodules of $\mathrm{R}+$ plants were $73.4 \pm 11.2$ (mean $\pm \mathrm{SE}$ ), $82.5 \pm 13.5$, and $103.7 \pm 21.6$ for the $\mathrm{R}+\mathrm{F}-, \mathrm{R}+\mathrm{F}+$, and $\mathrm{R}+\mathrm{F}++$ treatments, respectively, and $\mathrm{R}-$ plants had no root nodules. Neither the number nor the dry mass of root nodules differed among $\mathrm{F}$ treatments (one-way ANOVA, number of root nodules: $F_{2,40}=0.93, \quad P=0.404 ; \quad$ dry mass: $F_{2,40}=0.02$, $P=0.983)$.

\section{Nitrogen types in xylem sap}

Ureide- $\mathrm{N}$ of $\mathrm{R}+$ plants was significantly greater than that of $\mathrm{R}-$ plants and decreased with increasing soil nitrogen levels (two-way ANOVA, R: $F_{1,117}=54.46, P<0.001$, F: $\quad F_{2,117}=3.24, \quad P=0.044$, Fig. 1a). There was a significant interaction between $\mathrm{R}$ and $\mathrm{F}$ treatments $\left(F_{2,117}=3.48, P=0.035\right)$. In contrast, amino acid-N did not differ between $\mathrm{R}+$ and $\mathrm{R}-$ plants, but increased with increasing soil nitrogen levels (two-way ANOVA, R: $F_{1,117}=0.33, P=0.565, \mathrm{~F}: F_{2,117}=15.62, P<0.001$, Fig. 1b). Nitrate-N did not differ between $\mathrm{R}+$ and $\mathrm{R}-$ plants or among $\mathrm{F}$ treatments (two-way ANOVA, R: $F_{1,117}=0.05, P=0.817, \mathrm{~F}: F_{2,117}=2.81, P=0.065$,
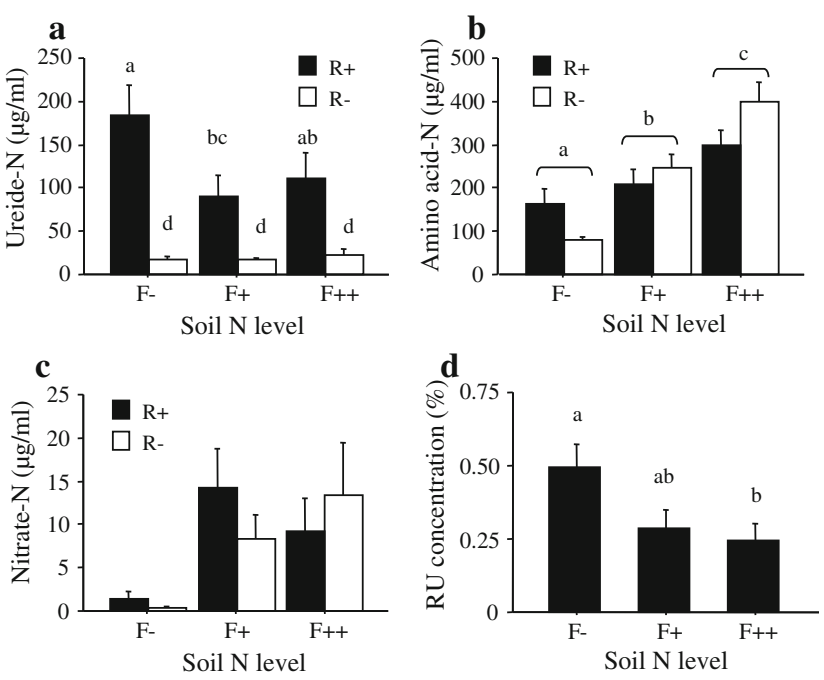

Fig. 1 a Ureide-N, b amino acid-N and c nitrate-N, and $\mathbf{d}$ relative ureide (RU) in xylem sap. Solid and open columns indicate rootnodulating $(\mathrm{R}+)$ and non-nodulating $(\mathrm{R}-)$ soybeans, respectively $(\mathrm{R}-\mathrm{F}-: n=25, \mathrm{R}-\mathrm{F}+: n=24, \mathrm{R}-\mathrm{F}++: n=25, \mathrm{R}+\mathrm{F}-: n=14$, $\mathrm{R}+\mathrm{F}+: n=15$, and $\mathrm{R}+\mathrm{F}++: n=14)$. Different letters show significant difference between treatments (Tukey-Kramer test, $P<0.05)$. Bars show SE

Fig. 1c). There were no significant interactions in amino acid-N and nitrate-N between $\mathrm{R}$ and $\mathrm{F}$ treatments (amino acid-N: $\quad F_{2,117}=2.50, \quad P=0.087, \quad$ nitrate-N: $\quad F_{2,117}=$ $0.63, P=0.534)$. As a result, the relative ureide concentration decreased with increasing soil nitrogen level (oneway ANOVA, $F_{2,40}=3.97, P=0.028$, Fig. $1 \mathrm{~d}$ ), suggesting that rhizobia activity was reduced in high soil nitrogen conditions.

\section{Soybean biomass}

The total biomass and leaf mass of $\mathrm{R}+$ plants were significantly greater than those of $\mathrm{R}-$ plants, and soil nitrogen increased them (two-way ANOVA, total biomass: R: $F_{1,117}=55.14, P<0.001$, F: $F_{2,117}=10.95, P<0.001$; leaf mass: R: $F_{1,117}=26.55, P<0.001, \mathrm{~F}: F_{2,117}=$ 11.66, $P<0.001$, Fig. 2a, b). There were no interactions between $\mathrm{R}$ and $\mathrm{F}$ treatments (total biomass: $F_{2,117}=0.23$, $P=0.795$; leaf mass: $F_{2,117}=0.46, P=0.635$ ).

\section{Chemical and nutrient status of leaves}

The foliar carbon and nitrogen of $\mathrm{R}+$ plants were significantly greater than those of $\mathrm{R}-$ plants, and soil nitrogen increased the plants' carbon and nitrogen concentrations (two-way ANOVA, carbon: R: $F_{1,117}=232.43, P<$ 0.001, F: $F_{2,117}=29.85, P<0.001$; nitrogen: R: $F_{1,117}=$ 111.95, $P<0.001$, F: $F_{2,117}=17.84, P<0.001$, Fig. 3a, b). There were significant interactions between $\mathrm{R}$ and $\mathrm{F}$ treatments (carbon: $F_{2,117}=18.04, P<0.001$; nitrogen: 

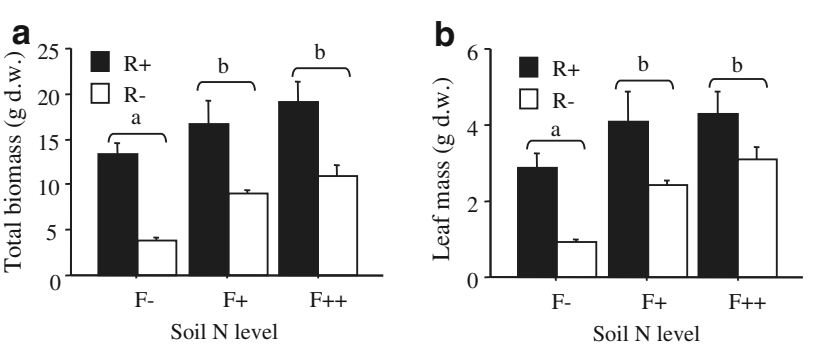

Fig. 2 a Total mass and b leaf mass of soybeans. Solid and open columns indicate root-nodulating $(\mathrm{R}+)$ and non-nodulating $(\mathrm{R}-)$ soybeans, respectively $(\mathrm{R}-\mathrm{F}-: n=25, \mathrm{R}-\mathrm{F}+: n=24, \mathrm{R}-\mathrm{F}++$ : $n=25, \mathrm{R}+\mathrm{F}-: n=14, \mathrm{R}+\mathrm{F}+: n=15$, and $\mathrm{R}+\mathrm{F}++: n=14)$. Different letters show significant difference between treatments (Tukey-Kramer test, $P<0.05$ ). Bars show SE
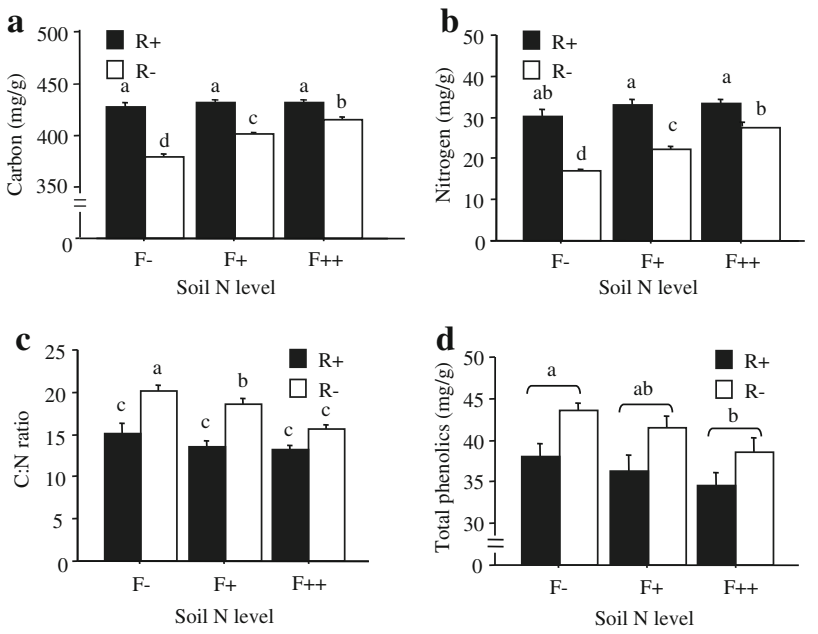

Fig. 3 a Carbon, b nitrogen, c C:N ratio, and d total phenolics in leaves. Solid and open columns indicate root-nodulating $(\mathrm{R}+)$ and non-nodulating $(\mathrm{R}-)$ soybeans, respectively $(\mathrm{R}-\mathrm{F}-: n=25, \mathrm{R}-\mathrm{F}+$ : $n=24, \mathrm{R}-\mathrm{F}++: n=25, \mathrm{R}+\mathrm{F}-: n=14, \mathrm{R}+\mathrm{F}+: n=15$, and $\mathrm{R}+\mathrm{F}++: n=14)$. Different letters show significant difference between treatments (Tukey-Kramer test, $P<0.05$ ). Bars show SE

$\left.F_{2,117}=5.78, P=0.004\right)$. Although the carbon and nitrogen concentrations of $\mathrm{R}+$ plants were not affected by soil nitrogen (post hoc test, $P>0.05$ ), carbon and nitrogen of $\mathrm{R}$ - plants gradually increased with soil nitrogen levels (post hoc test, $P<0.05$ ). As a result, the $\mathrm{C}: \mathrm{N}$ ratio of $\mathrm{R}+$ plants was significantly lower than that of $\mathrm{R}$ - plants, and an increase of soil nitrogen caused a decrease of the C:N ratio (two-way ANOVA, R: $F_{1,117}=83.62, P<0.001, \mathrm{~F}$ : $F_{2,117}=21.58, P<0.001$, Fig. $\left.3 \mathrm{c}\right)$. There was significant interaction between $\mathrm{R}$ and $\mathrm{F}$ treatments $\left(F_{2,117}=7.60\right.$, $P<0.001)$. Total phenolics of $\mathrm{R}+$ plants were less than those of R- plants, and soil nitrogen decreased the total phenolics concentration (two-way ANOVA, R: $F_{1,117}=$ 13.71, $P<0.001$, F: $F_{2,117}=3.44, P=0.035$, Fig. $\left.3 \mathrm{~d}\right)$. There was no significant interaction between $\mathrm{R}$ and $\mathrm{F}$ treatments $\left(F_{2,117}=0.15, P=0.861\right)$.
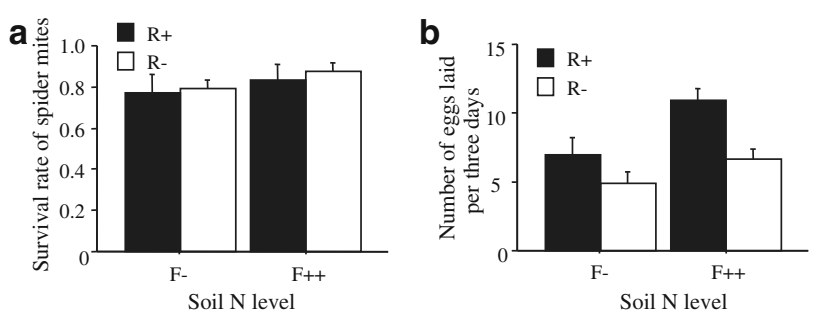

Fig. 4 a Survival rate and $\mathbf{b}$ egg production of a spider mite in 3 days. Solid and open columns indicate root-nodulating $(\mathrm{R}+)$ and nonnodulating $(\mathrm{R}-)$ soybeans, respectively $(\mathrm{R}-\mathrm{F}-: n=6, \mathrm{R}-\mathrm{F}++$ : $n=12, \mathrm{R}+\mathrm{F}-: n=6$, and $\mathrm{R}+\mathrm{F}++: n=9)$. Different letters show significant difference between treatments (Tukey-Kramer test, $P<0.05)$. Bars show SE

Rhizobia effect on spider mite survival and oviposition

More than $77 \%$ of the spider mites survived for 3 days, and the survival rate did not differ between $\mathrm{R}$ and $\mathrm{F}$ treatments (nominal logistic regression, $\mathrm{R}: \chi_{1,258}^{2}=0.35, P=0.557$, F: $\quad \chi_{2,258}^{2}=2.74, \quad P=0.098, \quad \mathrm{R} \times \mathrm{F}: \quad \chi_{2,258}^{2}<0.01$, $P=0.996$, Fig. 4a). Egg production by spider mites was enhanced by $\mathrm{R}$ and $\mathrm{F}$ treatments (two-way ANOVA, R: $F_{1,31}=13.67, P<0.001$, F: $F_{1,31}=11.20, P=0.002$, Fig. 4b). There was no interaction in egg production between $\mathrm{R}$ and $\mathrm{F}$ treatments $\left(F_{1,31}=1.69, P=0.204\right)$.

\section{Discussion}

Effects of rhizobia on plant quality and susceptibility to spider mites

This study clearly demonstrated that rhizobia modified the chemical and nutrient status of soybean, leading to enhanced plant susceptibility to the spider mites. $R+$ plants produced a greater number of leaves with higher nitrogen and lower phenolics than $\mathrm{R}-$ plants. Spider mites fed on $\mathrm{R}+$ leaves produced more eggs than those fed on $\mathrm{R}-$ leaves. The increased plant susceptibility may have been caused by at least two factors. First, rhizobia increased the nitrogen level in the plants. For many herbivorous arthropods, nitrogen is an important factor in determining their growth and/or reproduction (Mattson 1980; Mattson and Scriber 1987; White 1993). In fact, higher leaf nitrogen can increase the fecundity of spider mites (Wermelinger et al. 1985; Wilson et al. 1988). Therefore, high leaf nitrogen provides high-quality resources to spider mites. Second, rhizobia decreased the phenolics concentration in the leaves. Phenolics are defensive substances against many arthropod herbivores (Feeny 1970; Bryant et al. 1987; Dudt and Shure 1994), including spider mites (Larson and Berry 1984). Although we know little about the effects of rhizobia on the performance of aboveground arthropods, 
decreased phenolics and increased nitrogen levels might be underlying mechanisms responsible for the enhanced reproduction of the spider mites observed here.

It is practically impossible to completely remove rhizobia in potted soybeans during the experiment because belowground bacteria easily colonize in the field. Therefore, we used a closely related non-nodulating strain to the nodulating strain. Likewise, Kempel et al. (2009) examined the effects of rhizobia on performances of aboveground lepidopteran caterpillars and aphids, using a non-nodulating mutant of white clover. It is more likely that difference in the egg production of spider mites was caused by rhizobia, although a possibility that other traits of non-nodulating plants related to resistance to spider mites differ from those of nodulating plants is not excluded.

Recent studies have paid much attention to the effects of belowground symbiotic microbes on aboveground plantarthropod interactions (Gange 2007; Hartley and Gange 2009). For example, it has been shown that reproductive traits of aboveground herbivorous arthropods can be positively or negatively affected by belowground arbuscular mycorrhizal fungi (Gange et al. 1999; Goverde et al. 2000). In their meta-analysis using 34 studies, Koricheva et al. (2009) showed that performance of mesophyll feeders was decreased by mycorrhizal fungi colonization, but performance of sucking insects was increased. For example, Gange et al. (1999) reported that the fecundity of two species of aphids (Myzus persicae and M. ascalonicus) was enhanced when the aphids fed on mycorrhiza-infected Plantago. Likewise, spider mites (T. urticae) fed on mycorrhiza-infected plants showed increased egg production (Hoffmann et al. 2009) although this pattern was in contrast to the findings Koricheva et al. (2009). There is increasing evidence that mycorrhizal fungi influence reproductive traits of aboveground arthropods. However, to date we know little about the effects of nitrogen-fixing bacteria (but see Kempel et al. 2009).

Endophytes living in leaves directly provide defensive substances to host plants. For example, Neotyphodium endophyte produces alkaloids in the host plant and makes host plants toxic to herbivores (Carroll 1988; Bush et al. 1997). In contrast to the plant-endophyte interaction, rhizobia are not likely to produce toxic substances, but do provide nitrogen to host plants. Thus, modification of the nutrient status by rhizobia may indirectly influence the defensive status of host plants. It is known that the carbonbased chemical substances in leaves change depending on the resource availability in the soil (Bryant et al. 1983; Coley et al. 1985; Bazzaz et al. 1987; Denslow et al. 1990), and that nitrogen-fertilization reduces the concentrations of carbon-based secondary metabolites (Bryant et al. 1987). This is partly because of a metabolic trade-off between the syntheses of leaf proteins and carbon-based phenolics (protein competition model: Jones and Hartley 1999). Since rhizobia provide nitrogen to host plants, it is likely that an increase in foliar nitrogen by rhizobia association causes a decrease in foliar phenolics.

Rhizobia activity and its effects on spider mites at different soil nitrogen levels

In this study, we also evaluated the effect of soil nitrogen level on rhizobia activity by assessing nitrogen types in xylem sap. Although root nodule mass did not differ among $\mathrm{F}$ treatments, ureide- $\mathrm{N}$, an indicator of nitrogen provided by rhizobia, in xylem sap decreased at moderate and high soil nitrogen levels. In contrast, amino acid-N in xylem sap, an indicator of nitrogen derived from soil, increased with increasing soil nitrogen levels. Nitrate- $\mathrm{N}$ in xylem sap, another indicator of nitrogen derived from soil, was not influenced by the soil nitrogen level, although its concentration was considerably lower than those of ureide$\mathrm{N}$ and amino acid-N. Thus, the rhizobia activity is most likely to decrease with increasing soil nitrogen level. This result agrees with the conclusion that rhizobia activity decreased when fertilized (Evans 1982; Hardarson and Zapata 1984).

We expected that rhizobia effects on spider mite egg production would decrease in high soil nitrogen conditions. However, this was not the case; rather the effect of rhizobia was still maintained even at high soil nitrogen level with low rhizobia activity. In this study, the foliar nitrogen of $\mathrm{R}+$ plant was significantly higher than that of $\mathrm{R}-$ plants at high soil nitrogen levels. Also, the total phenolics of $\mathrm{R}+$ plants tended to be less than those of $\mathrm{R}-$ plants. Thus, soil nitrogen and rhizobia may independently affect the reproductive performance of the spider mite, or soil nitrogen may enhance the effects of rhizobia.

This result suggests that the effects of rhizobia on herbivore performance were not cancelled out at high soil fertility. Although modification of the nutrient status by rhizobia may indirectly increase or decrease the strength of host plant resistance, the positive effects of rhizobia may be not only due to simply an increase in the availability of nitrogen for the plant. Because Pozo and Azcón-Aguilar (2007) suggested that belowground mycorrhizal fungi directly promote plant defense systems by influencing the jasmonate-dependent signaling pathway, rhizobia may also influence plant resistance independent of the nitrogen supply to host plants. However, the underlying mechanisms of rhizobia-driven plant resistance related to nitrogenbased secondary compounds are little understood, and thus the effect of the nodulating gene on plant resistance remains unclear.

All legume plants have obligate symbiosis with rhizobia. It is known that legumes are key ecosystem drivers that 
determine ecosystem productivity (Aarssen 1997; Mulder et al. 2002) and influence arthropod diversity in terrestrial systems (Siemann 1998). Although recent studies have emphasized that rhizobia act as a determinant of plant community structure and diversity (van der Heijden et al. 2006, 2008), legume-rhizobia-aboveground arthropod interactions have remained poorly explored. Our study clearly demonstrated that rhizobia indirectly enhanced egg production of the spider mites through changes in plant quality. Future studies need to pay more attention to rhizobia effects to better understand aboveground plantarthropod interactions.

Acknowledgments We thank Dr. Takatoshi Tanisaka for providing soybean seeds, and Drs. Tatsuhiko Shiraiwa, Keisuke Katsura, Junko Sato, and Koji Takahashi for advising us on the cultivation of soybeans and how to analyze xylem sap. We thank the Federation of Tokachi Agricultural Cooperative Association for providing rhizobium. We also thank Drs. Hideki Kagata and Shunsuke Utsumi for helpful comments during this experiment, and Dr. Elizabeth Nakajima for correcting the English of this text. This study was supported by the Ministry of Education, Culture, Sports, Science, and Technology Grant-in-Aid for Scientific Research (A-15207003 and B-20370010) to T. Ohgushi, the 21st Century COE program (A14) and the Global COE program (A06) to Kyoto University, and JSPS Research Fellowships for Young Scientist to N. Katayama and T. Nishida.

\section{References}

Aarssen LW (1997) High productivity in grassland ecosystems: effected by species diversity or productive species? Oikos 80:183-184

Bascompte J, Jordano P (2007) Plant-animal mutualistic networks: the architecture of biodiversity. Annu Rev Ecol Evol Syst 38:567-593

Bazzaz FA, Chiariello NR, Coley PD, Pitelka LF (1987) Allocating resources to reproduction and defense. Bio Sci 37:58-67

Bryant JP, Chapin FS III, Klein DR (1983) Carbon/nutrient balance of boreal plants in relation to vertebrate herbivory. Oikos 40:357-368

Bryant JP, Chapin FS III, Reichardt PB, Clausen TP (1987) Response of winter chemical defense in Alaska paper birch and green alder to manipulation of plant carbon/nutrient balance. Oecologia 72:510-514

Bush LP, Wilkinson HH, Schardl CL (1997) Bioprotective alkaloids of grass-fungal endophyte symbioses. Plant Physiol 114:1-7

Carroll G (1988) Fungal endophytes in stems and leaves: from latent pathogen to mutualistic symbiont. Ecology 69:2-9

Cataldo DA, Schrader LE, Youngs VL (1974) Analysis by digestion and colorimetric assay of total nitrogen in plant tissues high in nitrate. Crop Sci 14:854-856

Chaneton EJ, Omacini M (2007) Bottom-up cascades induced by fungal endophytes in multitrophic systems. In: Ohgushi T, Craig TP, Price PW (eds) Ecological communities: plant mediation in indirect interaction webs. Cambridge University Press, Cambridge, pp 124-144

Choh Y, Ozawa R, Takabayashi J (2004) Effects of exogenous jasmonic acid and benzo(1,2,3)thiadiazole-7-carbothioic acid $S$ methyl ester (BTH), a functional analogue of salicylic acid, on the egg production of a herbivorous mite Tetranychus urticae (Acari: Tetranychidae). App Entomol Zool 39:311-314
Clay K (1988) Fungal endophytes of grasses: a defensive mutualisms between plants and fungi. Ecology 69:10-16

Coley PD, Bryant JP, Chaoin FS III (1985) Resource availability and plant antiherbivore defense. Science 230:895-899

Denslow JS, Schultz JC, Vitousek PM, Strain BR (1990) Growth response of tropical shrubs to treefall gap environments. Ecology 71:165-179

Dudt JF, Shure DJ (1994) The influence of light and nutrients on foliar phenolics and insect herbivory. Ecology 75:86-98

Edathil TT, Manian S, Udaiyan K (1996) Interaction of multiple VAM fungal species on root colonization plant growth and nutrient status of tomato seedlings (Lycopersicon esculentum Mill.). Agric Ecosyst Environ 59:63-68

Evans J (1982) Response of soybean-Rhizobium symbioses to mineral nitrogen. Plant Soil 66:439-442

Feeny PP (1970) Seasonal changes in oak leaf tannins and nutrients as a cause of spring feeding by winter moth caterpillars. Ecology $51: 565-581$

Gange AC (2007) Insect-mycorrhizal interactions patterns, processes and consequence. In: Ohgushi T, Craig TP, Price PW (eds) Ecological communities: plant mediation in indirect interaction webs. Cambridge University Press, Cambridge, pp 124-144

Gange AC, West HM (1994) Interaction between arbuscular-mycorrhizal fungi and foliar-feeding insects in Plantago lanceolata L. New Phytol 128:79-87

Gange AC, Bower E, Brown VK (1999) Positive effects of arbuscular mycorrhizal fungus on aphid life history traits. Oecologia 120:123-131

Goverde M, van der Heijden MGA, Wiemken A, Sanders IR, Erhardt A (2000) Arbuscular mycorrhizal fungi influence life history traits of a lepidopteran herbivore. Oecologia 125:362-369

Hardarson G, Zapata F (1984) Effect of plant genotype and nitrogen fertilizer on symbiotic nitrogen fixation by soybean cultivars. Plant Soil 82:397-405

Hartley SE, Gange AC (2009) Impacts of plant symbiotic fungi on insect herbivores: mutualism in a multitrophic context. Annu Rev Entomol 54:323-342

Herridge DF (1984) Effect of nitrate and plant development on the abundance of nitrogenous solutes in root-bleeding and vacuumextracted exudates of soybean. Crop Sci 24:173-179

Herridge DF, Peoples MB (1990) Ureide assay for measuring nitrogen fixation by nodulated soybean calibrated by ${ }^{15} \mathrm{~N}$ methods. Plant Physiol 93:495-503

Hoffmann D, Vierheilig H, Riegler P, Schausberger P (2009) Arbuscular mycorrhizal symbiosis increases host plant acceptance and population growth rates of the two-spotted spider mite Tetranychus urticae. Oecologia 158:663-671

Ings TC, Montoya JM, Bascompte J, Blüthgen N, Brown L, Dormann CF, Edwards F, Figueroa D, Jacob U, Jones JI, Lauridsen RB, Ledger ME, Lewis HM, Olesen JM, van Veen FJ, Warren PH, Woodward G (2009) Ecological networks-beyond food webs. J Anim Ecol 78:253-269

Jones CE, Hartley SE (1999) A protein competition model of phenolic allocation. Oikos 86:27-44

Julkunen-Tiitto R (1985) Phenolics constituents in the leaves of northern willows: methods for the analysis of certain phenolics. J Agric Food Chem 33:213-217

Kempel A, Brandl R, Schädler M (2009) Symbiotic soil microorganisms as players in aboveground plant-herbivore interactions - the role of rhizobia. Oikos 118:634-640

Koricheva J, Gange AC, Jones T (2009) Effects of mycorrhizal fungi on insect herbivores: a meta-analysis. Ecology 90:2088-2097

Larson KC, Berry RE (1984) Influence of peppermint phenolics and monoterpenes on two spotted spider mite (Acari: Tetranychidae). Environ Entomol 13:282-285 
Mathews A, Carroll BJ, Gresshoff PM (1987) Characterization of non-nodulating mutants of soybean [Glycine $\max (\mathrm{L}$.$) Merr]:$ Bradyrhizobium effects and absence of root hair curling. J Plant Physiol 131:349-361

Matsumoto T, Yatazawa M, Yamamoto Y (1977) Distribution and change in the contents of allantoin and allantoic acid in developing nodulating and non-nodulating soybean plants. Plant Cell Physiol 18:353-359

Mattson WJ (1980) Herbivory in relation to plant nitrogen concentration. Annu Rev Ecol Syst 11:119-161

Mattson WJ, Scriber JM (1987) Nutritional ecology of insect folivores of woody plants: nitrogen, water, fiber, and mineral considerations. In: Slansky F, Rodrigues JG (eds) Nutritional ecology of insects mites spiders, and related invertebrates. Wiley, New York, pp 105-146

Miklashevichs E, Röhrig H, Schell J, Schmidt J (2001) Perception and signal transduction of rhizobial NOD factors. Crit Rev Plant Sci 20:373-394

Mulder CPH, Jumpponen A, Högberg P, Huss-Danell K (2002) How plant diversity and legumes affect nitrogen dynamics in experimental grassland communities. Oecologia 133:412-421

Navajas M (1998) Host plant associations in the spider mite Tetranychus urticae (Acari: Tetranychidae): insights from molecular phylogeography. Exp Appl Acarol 22:201-214

Ohgushi T (2005) Indirect interaction webs: herbivore-induced effects through trait change in plants. Annu Rev Ecol Evol Syst 36:81105

Ohgushi T (2008) Herbivore-induced indirect interaction webs on terrestrial plants: the importance of non-trophic, indirect, and facilitative interactions. Entomol Exp Appl 128:217-229

Ohgushi T, Craig TP, Price PW (2007) Ecological communities: plant mediation in indirect interaction web. Cambridge University Press, Cambridge

Omacini M, Chaneton EJ, Ghersa CM, Müller CB (2001) Symbiotic fungal endophytes control insect host-parasite interaction webs. Nature 409:78-81

Patriarca EJ, Tatè R, Iaccarino M (2002) Key role of bacterial $\mathrm{NH}_{4}{ }^{+}$ metabolism in rhizobium-plant symbiosis. Microbiol Mol Biol Rev 66:203-222

Poelman EH, van Loon JJA, Dicke M (2008) Consequences of variation in plant defense for biodiversity at higher trophic levels. Trends Plant Sci 13:534-541

Pozo MJ, Azcón-Aguilar C (2007) Unraveling mycorrhiza-induced resistance. Curr Opin Plant Biol 10:393-398

Rudgers JA, Clay K (2008) An invasive plant-fungal mutualism reduces arthropod diversity. Ecol Lett 11:831-840

Saeidi Z, Mallik B (2006) In vitro screening of 67 Lycopersicon accessions/cultivars for resistance to two-spotted spider mite. J Biol Sci 6:847-853
Siemann E (1998) Experimental tests of effects of plant productivity and diversity on grassland arthropod diversity. Ecology 79:2057-2070

Smith SE, Read DJ (1997) Mycorrhizal symbiosis. Academic Press, San Diego

Stonor SK, Stringfellow T (1967) Resistance of tomato varieties of spider mite. Proc Am Soc Hort Sci 90:324-329

Streeter JG (1979) Allantoin and allantoic acid in tissues and stem exudates from field-grown soybean plants. Plant Physiol 63:478480

Suganuma N, Kanada H, Yanagimoto N (1991) Detection of polypeptides involved in early stages of nodulation in soybean roots. Plant Cell Physiol 32:1259-1266

Unkovich MJ, Pate JS (2000) An appraisal of recent field measurements of symbiotic $\mathrm{N}_{2}$ fixation by annual legumes. Field Crop Res 65:211-228

van der Heijden MGA, Bakker R, Verwaal J, Scheublin TR, Rutten M, van Logtestijn R, Staehelin C (2006) Symbiotic bacteria as a determinant of plant community structure and plant productivity in dune grassland. FEMS Microbiol Ecol 56:178-187

van der Heijden MGA, Bardgett RD, van Straalen NM (2008) The unseen majority: soil microbes as drivers of plant diversity and productivity in terrestrial ecosystems. Ecol Lett 11:296-310

van Rhijn P, Vanderleyden J (1995) The rhizobium-plant symbiosis. Microbiol Rev 59:124-142

Van Zandt PA, Agrawal AA (2004) Community-wide impacts of herbivore-induced plant responses in milkweed (Asclepias syriaca). Ecology 85:2616-2629

Vicari M, Hatcher PE, Ayres PG (2002) Combined effect of foliar and mycorrhizal endophytes on an insect herbivore. Ecology 83:2452-2464

Wermelinger B, Oertli JJ, Delucchi V (1985) Effect of host plant nitrogen fertilization on the biology of the two-spotted spider mite, Tetranychus urticae. Entomol Exp Appl 38:23-28

White TCR (1993) The inadequate environment: nitrogen and the abundance of animals. Springer, Berlin

Williams LF, Lynch DL (1954) Inheritance of a non-nodulating character in the soybean. Agron J 46:28-29

Wilson LT, Smilanick JM, Hoffmann MP, Flaherty DL, Ruiz SM (1988) Leaf nitrogen and position in relation to population parameters of pacific spider mite, Tetranychus pacificus (Acari: Tetranychidae) on grapes. Environ Entomol 17:964-968

Young EG, Conway CF (1942) On the estimation of allantoin by the Rimini-Schryver reaction. J Biol Chem 142:839-853

Zar JH (1999) Biostatistical analysis, 4th edn. Prentice Hall, New Jersey 